\title{
Evaluating Potential Changes in Fire Risk from Eucalyptus Plantings in the Southern United States
}

\author{
Scott L. Goodrick and John A. Stanturf \\ Center for Forest Disturbance Science, USDA Forest Service, 320 Green Street, Athens, GA 30602, USA \\ Correspondence should be addressed to John A. Stanturf, drdirt48@gmail.com
}

Received 19 July 2012; Revised 23 November 2012; Accepted 29 November 2012

Academic Editor: Matias Kirst

Copyright ( $) 2012$ S. L. Goodrick and J. A. Stanturf. This is an open access article distributed under the Creative Commons Attribution License, which permits unrestricted use, distribution, and reproduction in any medium, provided the original work is properly cited.

\begin{abstract}
Renewed interest in short-rotation woody crops for bioenergy and bioproducts has prompted a reevaluation of the Eucalyptus species for the southern United States. One question that arises about the potential effects of introducing a nonnative species is what effect will there be on fire behavior. Our approximate answer based on modeling fire behavior using the Fuel Characteristic Classification System is that surface fire behavior in young stands differs little from surface fires common to pine plantations in the southern Coastal Plain. By the age of 9, the absence of a shrub layer, along with an increased height to live crown, reduced initiation potential despite increased bark shedding. When a shrub layer was introduced in the model, the initiation potential became equivalent to common Pinus fuelbeds. If a crown is ignited, however, the potentials for transmissivity and spread are very high, and the potential for crown fire behavior is more severe. Our modeling effort suggests that fire behavior at the stand level differs little from current conditions and points to the importance of avoiding the development of a shrub layer. Stands managed on short rotation (less than 10 years) will likely be harvested before bark shedding presents a significant spotting problem.
\end{abstract}

\section{Introduction}

The southern United States is one of the most productive forested regions in the country, with 81 million ha or 40 percent of the nation's forests in an area occupying only 24 percent of its land area [1]. Commercial forestry in the Coastal Plain along the Atlantic Ocean and the Gulf of Mexico depends upon plantations of Pinus spp. and naturally regenerated broadleaved forests [2]. Renewed interest in short-rotation woody crops (SRWC) for bioenergy and bioproducts [3] has prompted evaluation of other fast-growing species including Eucalyptus spp. [4]. The potential productivity of nonnative Eucalyptus species planted in the southern United States under short-rotation management for biomass is significantly greater than native Pinus species [4-7], and the economic potential of selected species has been evaluated for conversion into ethanol [8] or solid fuel [9]. Identification of freeze-tolerant Eucalyptus species and hybrids extends the potential commercial range for Eucalyptus well beyond current plantings in southern Florida, into the Coastal Plain $[4,7]$. Research underway to test
38 species for cold tolerance has identified five with some tolerance as well as fast growth; these species are E. benthamii Maiden \& Cambage, E. dorrigoensis (Blakely) L.A.S. Johnson \& K.D. Hill, E. viminalis Labill., E. dalrympleana Maiden, E. macarthurii H. Deane \& Maiden, and E. camaldulensis Dehnh. (José Luiz Stape, Professor, North Carolina State University, personal communication, 2012.) Commercial plantings on former pasture have already been initiated by MWV Corporation to provide hardwood furnish to its Evadale, Texas mill. (Dave Gerhardt, Director, Operations Support, MWV, personal communications, 2012.)

Although new SRWC plantations for bioenergy will likely be established on idle agricultural land because of lower establishment costs and legislative prohibitions [3], reforesting harvested Pinus plantations with Eucalyptus cannot be ruled out. Attractive economics could drive conversion of pine plantations for pulp and other bioproducts to Eucalyptus [6]. Introduction of non-native species for widespread commercial plantings is a new phenomenon in the United States and raises questions as to potential environmental effects. One question is what would be the effect on wildfire 
risk? Eucalyptus species in their native habitat are noted for their adaption to wildfire. Introduction of select Eucalyptus species into the southern Coastal Plain, an area known for fire-adapted ecosystems, raises the question of how will fire behavior in Eucalyptus stands differ from fires in commonly occurring vegetation? We sought an approximate answer to this question from the literature that focuses on fuel characteristics, loads, and the potential for fire behavior as modeled by the Fuel Characteristic Classification System (FCCS) [10]. The FCCS [11] will be used to compare fire potential for fuelbeds common in the southeastern Coastal Plain with representative fuelbeds for Eucalyptus plantations at several ages. The surface fire behavior component of FCCS is based on a modified form of Rothermel's equations that take into account the more complex description of a fuelbed provided by FCCS. Fire potential ratings using FCCS consist of numerical rating for surface fire behavior potential, crown fire potential, and available fuel potential for weather conditions characteristic of severe burning conditions [11]. Discussion will focus on the differences among typical southern fuelbeds in terms of the FCCS fire potentials, the extent to which the weather assumptions in FCCS reflect those of the southeastern Coastal Plain, and the extent to which planting Eucalyptus species may alter fire behavior within plantation stands.

\section{Materials and Methods}

2.1. Southern Coastal Plain. The southern United States is comprised of the 13 states roughly south of the Ohio River and extending from Texas to the Atlantic Coast. The region primarily has a humid subtropical climate except for a tropical climate in southern Florida and a semiarid climate in western Texas and Oklahoma. Annual daily temperature averages range from $>21^{\circ} \mathrm{C}$ in southern Florida and Texas to $13-16^{\circ} \mathrm{C}$ in northern areas. Annual precipitation is 1270 $1780 \mathrm{~mm}$ in the Mid-South including Louisiana, Mississippi, Alabama, and Tennessee, areas of Georgia and Florida, and areas along the Atlantic coast. Precipitation reduces to 1015 and $1270 \mathrm{~mm}$ towards Atlantic coastal areas and northern areas of the region, and to 300 and $500 \mathrm{~mm}$ towards western Texas and Oklahoma (http://cdo.ncdc.noaa.gov/cgibin/climaps/climaps.pl). Seasonal weather variability is significant in most of the region which is characterized by hot, humid summers and mild to cool winters. The major weather and climate extremes include tornados, hurricanes, excessive lightning, and drought-with drought being the largest contributor to large wildfires.

The complex role that wildfire plays in shaping forests has been described in terms of vegetation responses, which are characterized as dependent on, sensitive to, independent of, or influenced by fire [12]. Fire is essential in areas where species have evolved to withstand burning and facilitate the spread of fire such as the Pinus spp. found in the Coastal Plain. The fire regimes of southern ecosystems have been described in detail [13-15]. The Coastal Plain is dominated by plantations and open pine (Pinus spp.) stands-with perennial grasses and forbs as the primary ground fuel. Major pine species are longleaf ( $P$. palustris Mill.), slash ( $P$.

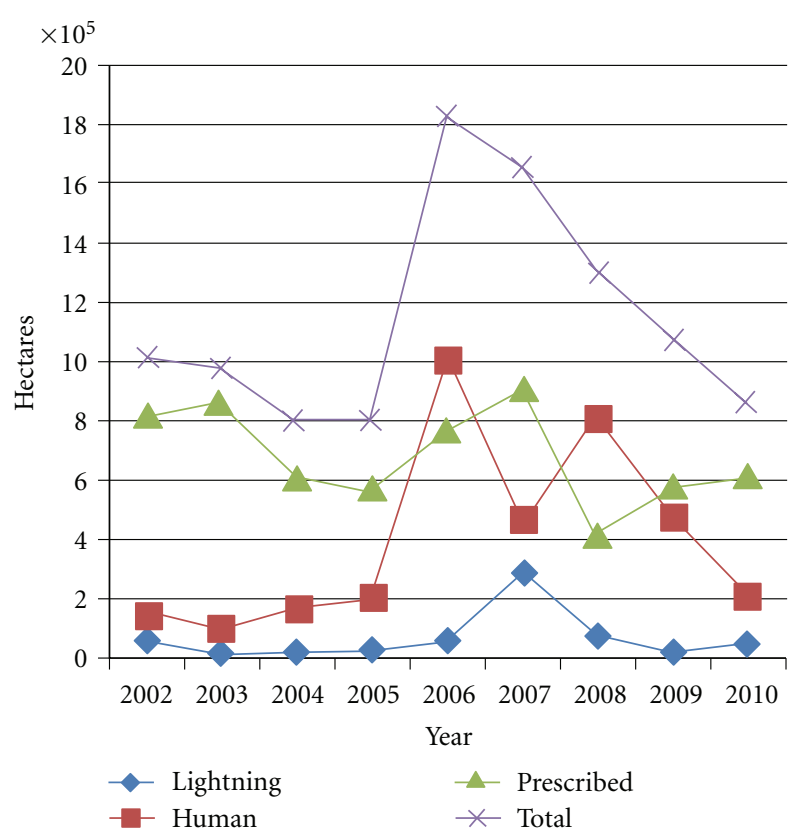

FIGURE 1: Area burned in the southern United States by fires of various ignition sources, 2002 to 2010 (Data from National Interagency Fire Center; http://www.nifc.gov/fireInfo/fireInfo_statistics.html accessed 9 July 2012).

elliottii Engelm.), and loblolly (P. taeda L.) pines [2, 14, 15]. Before European settlement, frequent low-severity surface fires characterized most Coastal Plain ecosystems with a return interval of 1-4 years; windstorms (including hurricanes) and droughts led to occasional severe fires [16].

Today, southern Coastal Plain forests are dynamic ecosystems characterized by rapid growth-and hence rapid accumulation of fuels within a favorable climate-and a short fire-return interval of 3-5 years is considered desirable for managed forests [14]. In addition to reducing fuel loads, prescribed burning is used to promote wildlife, maintain biodiversity, and restore ecosystems [17]. The South leads the nation in annual wildfires, averaging approximately 45,000 fires a year from 1997 through 2003 [18]. The success of rapid initial attack and suppression, however, keeps most of these fires small [19]. The average area burned annually over the period 2002-2010 was 69,748 ha from wildfires ignited by lightning and 397,860 ha from human ignitions. In addition to wildfires, substantial areas are burned annually to reduce fuel loads; the average area burned by controlled fires (prescribed burning) over the same period was 680,606 ha. There is considerable year-to-year variation in the area burned (Figure 1). Although prescribed burning data are not yet available for 2011, area burned in that year by lightning ignitions was 427,674 ha and by human ignitions $1,147,593 \mathrm{ha}$; both greatly exceeding the annual average (2002-2009). The frequency of droughts across the region appears to be changing, and the period from the mid- to late-1990s may have been wetter than the long-term average [20]. For example, during the worst drought in more than a century, severe wildfires broke out around the Okefenokee 
National Wildlife Refuge on the Georgia-Florida border in the spring of 2007 when more than 243,000 ha burned.

The southern Coastal Plain is also a region of rapid land use change [21] with increasing expansion of residential areas into forested land $[22,23]$. The intermixing of suburban and urban areas, with an extensive road system, into a working forest landscape poses greater consequences for escaped prescribed fires and health and safety effects of smoke [24-27]. This is the dynamic ecological and social context into which Eucalyptus plantations will be introduced. Additionally, projections of future climate suggest an increased potential for wildfire in the South $[28,29]$.

2.2. Fuelbeds. Wildland fuelbed characteristics are complex both temporally and spatially, and the Fuel Characteristic Classification System (FCCS) provides a means of classifying these fuelbeds in terms of their capacity to support fire and consume fuels [11]. Within FCCS, a fuelbed represents a relatively homogeneous portion of the landscape that can be viewed as a distinct combustion environment and can be used to describe potential fire behavior and effects. FCCS fuelbeds are organized into six strata: canopy, shrubs, nonwoody fuels, woody fuels, litter-lichen-moss, and ground fuels. Version 2.2 of FCCS includes 290 fuelbeds that represent the major vegetation types of the United States. For a complete description of how fuelbeds are described in FCCS the reader is referred to Riccardi et al. [10] and Ottmar et al. [11].

The initial fuelbed used to begin developing our Eucalyptus plantations is FCCS fuelbed number 165 which represents a longleaf pine savanna: a mesic to wet savanna with very open, scattered longleaf pine canopy trees over a diverse herbaceous layer dominated by grasses and many forb species, 2-3 years after a prescribed fire. Transforming this fuelbed into a site suitable for a plantation required removing the pine overstory, leaving a fuelbed comprised of grasses and forbs (Table 1).

Development of the Eucalyptus fuelbeds in FCCS follows de Mar and Adshead [30] in their description of fuel and fire behavior in Blue Gum (Eucalyptus globulus Labill.) plantations of various ages in Australia. Fuels in their guide are described in terms of four main layers: surface fuel, near-surface fuel, elevated fuel, and bark fuel [31]. The surface fuel layer consists of some grasses in younger plantations and leaf litter, twigs, and shed bark. In FCCS, these fuels are split among the non-woody (grasses), litter (litter and bark) and the woody (twigs) strata. The near-surface and elevated fuel layers are mostly absent in plantations except for prolific grass growth in new plantations, heavy bark accumulations in long rotation (10+ years) plantations, or where shrubs have invaded along edges and in openings. The canopy strata in FCCS is determined based on stand information such as percent cover, stand density, tree height, height to live crown, and diameter at breast height. For purposes of this study, snags are not considered, and the only ladder fuel considered is stringybark for plantations older than 6 years. Eucalyptus plantation fuelbeds were built for 3, 6, and 9 years old plantations using growth rates following de Mar and Adshead [30]. Starting from an open grass dominated system
Table 1: Fuel load $\left(\mathrm{Mg} \mathrm{ha}^{-1}\right)$ for initial FCCS fuelbed 165 and starting point for plantation fuelbeds; fuelbed 165 is typical for a longleaf pine savanna with a herbaceous layer dominated by grasses and forbs, burned periodically.

\begin{tabular}{lcc}
\hline \multirow{2}{*}{ Fuelbed strata } & \multicolumn{2}{c}{ Fuelbed } \\
& FCCS 165 & Plantation, preplanting \\
\hline Canopy & 0.9 & 0 \\
Shrubs & 2.69 & 0 \\
Nonwoody & 0.9 & 0.9 \\
Woody & 1.57 & 0 \\
Litter & 2.69 & 0 \\
Ground & 2.91 & 0 \\
\hline
\end{tabular}

(Table 1), Eucalyptus trees are introduced at a stand density of 1000 trees per ha and planted in rows $3.5 \mathrm{~m}$ apart with $2.5 \mathrm{~m}$ between trees [31].

Once the plantations are described as FCCS fuelbeds, the FCCS software provides estimates of fire potential. Fire potentials in FCCS are summarized by a three -digit number with each digit representing an index describing an aspect of fire potential [32]. The first digit is the surface fire behavior potential (FBP), which is based on the Rothermel spread model [33] as modified by Sandberg et al. [34] to allow for more realistic descriptions of fuelbeds. The FBP has three subcomponents: a reaction potential representing the energy release per unit area per unit time, a spread potential proportional to the rate of spread, and a flame length potential estimating flame length under benchmark environmental conditions.

The second digit in FCCS is the crown fire potential (CFP) that utilizes a conceptual model for crown fire developed by Schaaf et al. [35] that has its roots in the crown fire research of Van Wagner [36], Alexander [37], and Scott and Reinhardt [38]. The CFP is in turn comprised of three components: (1) initiation potential (the likelihood that a surface fire will move into the crown), (2) transmissivity potential (the ability of fire to carry from crown to crown through a forest canopy), and (3) crown fire rate of spread.

The third digit of a fuelbed's fire potential in FCCS is the available fuel potential (AFP) which reflects the ovendry, combustible biomass. The total AFP is decomposed by combustion phase (flaming, smoldering, residual). Detailed descriptions of how each component is calculated can be found in the FCCS Users Guide [32, 39].

In order to consistently determine fire potential requires defining a benchmark set of environmental conditions that includes fuel moisture, topographic slope, and surface wind speed. The default environmental scenario in FCCS is for dry fuel conditions defined as BehavePlus fuel moisture (FM) scenario D2L2 [40]. This benchmark includes the following fuel moistures: $90 \%$ FM for the shrub layer, $60 \%$ FM for herbaceous, 6\% FM for the $1 \mathrm{hr}$ fuels, 7\% FM for the $10 \mathrm{hr}$ fuels, and $8 \% \mathrm{FM}$ for the $100 \mathrm{hr}$ fuels. These fuel moisture values represent very extreme conditions for the southern Coastal Plain and the resulting fire behavior ratings should 
TABLE 2: Fuel load $\left(\mathrm{Mg} \mathrm{ha}^{-1}\right)$ for Eucalyptus plantation fuelbeds at ages 3, 6, and 9 years.

\begin{tabular}{lccc}
\hline Fuelbed strata & 3 yr old & 6 yr old & 9 yr old \\
\hline Canopy & 5.83 & 30.48 & 37.44 \\
Shrubs & 0 & 0 & 0 \\
Nonwoody & 0.9 & 0.45 & 0.22 \\
Woody & 0 & 0.5 & 2 \\
Litter & 2 & 8 & 14 \\
Ground & 0 & 0 & 0 \\
\hline
\end{tabular}

TABLE 3: Fuel load $\left(\mathrm{Mg} \mathrm{ha}^{-1}\right)$ for typical pine fuelbeds in the southeastern United States.

\begin{tabular}{lccc}
\hline Fuelbed strata & $\begin{array}{c}\text { Slash pine plantation } \\
\text { (FCCS 156) }\end{array}$ & $\begin{array}{c}\text { Fuelbed } \\
\text { Longleaf and slash pine } \\
\text { forest with prescribed } \\
\text { burning (FCCS 191) }\end{array}$ & $\begin{array}{c}\text { Longleaf and slash pine } \\
\text { forest with fire exclusion } \\
\text { (FCCS 182) }\end{array}$ \\
\hline Canopy & 7.17 & 6.5 & 11.21 \\
Shrubs & 4.26 & 10.98 & 17.71 \\
Nonwoody & 0.22 & 0.45 & 0.45 \\
Woody & 13.45 & 4.04 & 2.91 \\
Litter & 6.5 & 6.73 & 11.66 \\
Ground & 21.07 & 9.42 & 81.6 \\
\hline
\end{tabular}

be viewed as worst case scenario. Slope is $0 \%$ slope, and a midflame wind speed of $6.44 \mathrm{~km} \mathrm{hr}^{-1}$ is assumed.

Fire potentials for the modeled Eucalyptus plantations are compared against three other FCCS fuelbeds common to the southern Coastal Plain. The first is FCCS fuelbed number 156 described as typical for a slash pine forest planted after a clearcut harvest less than 45 years ago; the stand was commercially thinned within the previous 2 years. The second FCCS fuelbed, number 191, describes the longleaf pine/slash pine/gallberry (Ilex glabra (L.) A. Gray) forest common throughout the southern Coastal Plain from Virginia south to Florida and west into Texas. This forest type is characterized by an open overstory of longleaf pine with occasional slash pine and a moderate to very dense shrub layer dominated by gallberry. Prescribed fire is used every 23 years to maintain an open structure and maintain a low shrub density. The third FCCS fuelbed, number 182, is the same forest type as the previous longleaf pine and slash pine forests, except that fire has been excluded for 30 or more years and a shrub layer has developed.

\section{Results}

Starting from an open grass-dominated system as described in the previous section, after 3 growing seasons, the trees are assumed to reach a height of $5 \mathrm{~m}$ with live branches and leaves retained from the ground up to the crown. As the trees develop and the canopy begins to close, the fine fuels begin to shift from being grass dominated to litter dominated as the canopy begins to shade out the grass. By the age of 6 , the trees are assumed to have grown to a height of $16 \mathrm{~m}$ with a height to live crown of $4 \mathrm{~m}$. Litter and woody debris are accumulating and adding to the fuel load as is bark shedding. By the age of 9 , the trees are assumed to reach a height of $20 \mathrm{~m}$ with a height to live crown of $15 \mathrm{~m}$. Litter has continued to accumulate at a rate of $2 \mathrm{Mg} \mathrm{ha}^{-1}$, while woody debris has accumulated at a rate of $0.5 \mathrm{Mgha}^{-1}$. The fuel loadings from FCCS based on these stand descriptions are shown in Table 2. For comparison, the fuel loads from FCCS fuelbeds common to the southern Coastal Plain are shown in Table 3. The rate of litter accumulation is greater in the Eucalyptus plantations than in the longleaf pine plantation that is periodically prescribed to burn and even exceeds the litter fuel load accumulated in the fire-excluded longleaf pine fuelbed. The canopy fuel load is an output of FCCS based on the stand parameters entered; the accumulation of canopy fuels also differs between the Eucalyptus and the southeastern pine fuelbeds. Although the Eucalyptus canopy fuel loads (more than $37 \mathrm{Mg} \mathrm{ha}^{-1}$ ) appear quite high compared to the southern Coastal Plain fuelbeds (about $11 \mathrm{Mgha}^{-1}$ stand with fire exclusion), fuelbeds for mature Hawaiian Eucalyptus plantations in FCCS have canopy fuel loads in excess of $65 \mathrm{Mg} \mathrm{ha}^{-1}$.

The fire potential estimates from FCCS increase for the Eucalyptus stand between 3 and 6 years of age but drop slightly between the ages of 6 and 9 (Table 4). The changes in surface fire behavior potential between ages 3 and 6 reflect the change in the surface fuel strata from grass to litter dominance. Crown closure between 3 and 6 years is not a factor because the environmental conditions used in FCCS specify a midflame wind speed, not an abovecanopy reference level wind. Between 6 and 9 years of age, the changes in surface fire behavior potential reflect an increasing fuel load and not a major shift in fuelbed composition as what happened between years 3 and 6 . The increased mass in the same fuelbed strata leads to increased reaction potential and slightly reduced spread surface potential. 
TABLE 4: FCCS fire behavior potentials for eucalyptus plantations at 3, 6, and 9 years after planting. FCCS potentials are index values.

\begin{tabular}{|c|c|c|c|}
\hline & 3 yr old & 6 yr old & 9 yr old \\
\hline Surface fire behaviour potential & 4 & 7 & 6 \\
\hline Reaction potential & 2.4 & 1.8 & 2.3 \\
\hline Spread potential & 3.7 & 7.3 & 6.4 \\
\hline Flame length potential & 2.1 & 2.5 & 2.8 \\
\hline Crown fire potential & 1 & 6 & 6 \\
\hline Initiation potential & 0 & 2.3 & 1.7 \\
\hline Transmissivity potential & 0 & 7.7 & 8.9 \\
\hline Spread potential & 3.2 & 9 & 8.6 \\
\hline Available fuel potential & 1 & 3 & 4 \\
\hline Flame available fuel potential & 0.6 & 2.8 & 3.6 \\
\hline Smoldering available fuel potential & 0 & 0 & 0 \\
\hline Residual available fuel potential & 0 & 0 & 0 \\
\hline FCCS fire potential code & 411 & 763 & 664 \\
\hline Flame length (m) & 0.34 & 0.49 & 0.61 \\
\hline Spread rate $\left(\mathrm{m} \mathrm{hr}^{-1}\right)$ & 62.18 & 245.06 & 184.71 \\
\hline
\end{tabular}

TABLE 5: FCCS fire behavior potentials for fuelbeds typical of the southeastern United States. FCCS potentials are index values.

\begin{tabular}{lccc}
\hline & $\begin{array}{c}\text { Slash pine } \\
\text { plantation (FCCS }\end{array}$ & $\begin{array}{c}\text { Longleaf and slash } \\
\text { pine forest with } \\
\text { prescribed fire } \\
\text { (FCCS 191) }\end{array}$ & $\begin{array}{c}\text { Longleaf and slash } \\
\text { pine forest with } \\
\text { fire exclusion } \\
\text { (FCCS 182) }\end{array}$ \\
\hline Surface fire behaviour potential & $156)$ & 7 & 8 \\
Reaction potential & 4 & 7.9 & 9 \\
Spread potential & 5.1 & 6.9 & 7.8 \\
Flame length potential & 4.2 & 5.7 & 6.4 \\
Crown fire potential & 3.8 & 2 & 4 \\
Initiation potential & 3 & 3.1 & 3.4 \\
Transmissivity potential & 2.7 & 0 & 7.2 \\
Spread potential & 7.2 & 2.7 & 3.5 \\
Available fuel potential & 2.1 & 2 & 6 \\
Flame available fuel potential & 3 & 1.4 & 1.9 \\
Smoldering available fuel potential & 1.6 & 0.4 & 3.7 \\
Residual available fuel potential & 1 & 0.1 & 0.3 \\
FCCS fire potential code & 0.1 & 722 & 846 \\
Flame length (m) & 433 & 2.44 & 3.14 \\
Spread rate (m hr ${ }^{-1}$ ) & 0.91 & 217.63 & 279.81 \\
\hline
\end{tabular}

Another major difference in fire potential between age 6 and 9 is reflected in the decline in the initiation potential for a crown fire. By age 6, crown closure has increased the transmissivity and spread potentials for the stand, but the absence of a shrub layer and the negligible amount of bark shedding keeps the initiation potential relatively low. By the age of 9, despite increased bark shedding, the absence of a shrub layer that would capture the bark and create a significant layer of ladder fuels, along with an increased height to live crown, further reduces the initiation potential. Note, however that in the event of initiation (ignition of the crown) the potentials for transmissivity and spread for a crown fire are very high.
FCCS surface fire behavior potentials do not show any major differences between the Eucalyptus plantations and the fuelbeds common to the southern Coastal Plain (Table 5). The southern pine forest fuelbeds appear likely to present a greater suppression problem than the Eucalyptus plantations due to similar spread rates but greater reaction potentials and flame lengths. In regard to crown fire, the southern Coastal Plain fuelbeds show higher initiation potentials but generally lower transmissivity and spread potentials. The longleaf and slash pine forest with unmanaged fuels (FCCS fuelbed 182) presented the greatest fire potential of any of the fuelbeds. The Eucalyptus plantations did not present an appreciable difference compared to the other southern pine fuelbeds. 
TABLE 6: Effect of introducing a shrub layer on FCCS fire behavior potentials for $9 \mathrm{yr}$ old eucalyptus plantation, as compared to a longleaf/slash pine stand with the shrub layer managed by periodic prescribed burning.

\begin{tabular}{|c|c|c|c|}
\hline & $\begin{array}{l}9 \text { yr old eucalyptus } \\
\text { plantation }\end{array}$ & $\begin{array}{c}9 \text { yr old eucalyptus } \\
\text { plantation with } \\
\text { shrub layer }\end{array}$ & $\begin{array}{l}\text { Longleaf and slash } \\
\text { pine forest with } \\
\text { prescribed burning } \\
\text { (FCCS 191) }\end{array}$ \\
\hline Surface fire behaviour potential & 6 & 7 & 7 \\
\hline Reaction potential & 2.3 & 4 & 7.9 \\
\hline Spread potential & 6.4 & 7.9 & 6.9 \\
\hline Flame length potential & 2.8 & 4.2 & 5.7 \\
\hline Crown fire potential & 6 & 6 & 2 \\
\hline Initiation potential & 1.7 & 3.1 & 3.1 \\
\hline Transmissivity potential & 8.9 & 8.9 & 0 \\
\hline Spread potential & 8.6 & 9 & 2.7 \\
\hline Available fuel potential & 4 & 4 & 2 \\
\hline Flame available fuel potential & 3.6 & 3.9 & 1.4 \\
\hline Smoldering available fuel potential & 0 & 0 & 0.4 \\
\hline Residual available fuel potential & 0 & 0 & 0.1 \\
\hline FCCS fire potential code & 664 & 764 & 722 \\
\hline Flame length (m) & 0.61 & 1.31 & 2.44 \\
\hline Spread rate $\left(\mathrm{m} \mathrm{hr}^{-1}\right)$ & 184.71 & 248.7 & 217.63 \\
\hline
\end{tabular}

Even though the Eucalyptus fuelbeds did not differ markedly from the southern pine fuelbeds with regard to surface fire behavior, the crown fire potential could be a concern as the transmissivity and spread potentials for the Eucalyptus fuelbeds are so high. The only factor mitigating the crown fire potential for the Eucalyptus is the low initiation potential. One assumption made in constructing the plantation fuelbeds was that the shrub layer would be suppressed in some manner (most likely by herbicides in commercial Eucalyptus plantations). Although shrubs are not likely to proliferate under closed Eucalyptus canopies, the level of undergrowth suppression can vary by Eucalyptus species and water availability [41]. To test the impact of this assumption, the shrub layer from the longleaf pine forest managed with prescribed fire was introduced into the 9-year-old Eucalyptus plantations (Table 6). The introduced shrub layer increased all aspects of surface fire behavior potential and raised the crown fire initiation potential to equal that of the managed pine forest. Without the shrub layer, it was possible to somewhat dismiss the crown fire potential of the Eucalyptus stands due to the low initiation potential; however, the introduced shrub layer raises the initiation potential to levels equivalent to the other southern Coastal Plain fuelbeds except that the potential crown fire behavior in the event of ignition is much more severe.

\section{Discussion}

Surface fire behavior in young Eucalyptus plantations differs little from surface fires in fuels common to the pine forests in the southern Coastal Plain. Eucalyptus is better known, however, for its crown fires and spotting behavior. The FCCS crown fire potential reflects this rather well; after 6 years, a
Eucalyptus plantation scores higher than any of the typical southern pine fuelbeds in transmissivity and spread potential. The crown fire initiation potential in the plantation environment is lower than in naturally regenerated stands as it is assumed that the higher tree density and possible management actions will suppress the shrub layer and thereby limit the development of an elevated fuel layer. If a shrub layer does develop, the initiation potential will be comparable to the native fuelbeds and will therefore increase the fire risk of a Eucalyptus plantation above that of the other fuel types.

It is difficult to compare the fuel loads in these hypothetical fuelbeds with those of Project Vesta [42], a major effort to characterize and model fire behavior in Australian Eucalyptus forests, as the projections of changes in fuel load through time made in Project Vesta are for established Eucalyptus forests recovering after a fire rather than freshly planted plantations. However it does appear that our fuel load estimates are greater. In Project Vesta, the mean rate of surface accumulation over the first ten years following a fire was approximately $1 \mathrm{Mgha}^{-1}$, half the rate used in the current study. Surface fuel accumulation rates given by de Mar and Adshead [30] ranged from 1 to $2 \mathrm{Mg} \mathrm{ha}^{-1}$, putting Vesta estimates at the low end of accumulation rates and the current study at the high end. As our intent was to supply information on changes in fire risk, erring toward the high end is preferable as it will bias our fire potential estimates towards a worst case event.

All fire behavior potentials produced using FCCS assumed a default set of environmental conditions. Comparison of these conditions to the historical weather conditions found in the Southern Wildfire Risk Assessment [43] reveals that the conditions in FCCS are fairly representative of the 97 th percentile conditions used in the risk assessment 
for the southern Coastal Plain [43]. Although a minor fraction of fires in the southern Coastal Plain occurs at these moisture levels, nevertheless the majority of hectares burned by wildfires happens under the most extreme weather conditions. While it is true that most wildfires ignited by lighting occur during the wet season, most of the area burned by these fires occurs at the very start of the wet season when fuels are at their driest. Additionally most wildfires in the southern Coastal Plain are human caused [18]. Even though the FCCS weather conditions reflect severe conditions in the southern Coastal Plain fairly well, these conditions are at the lower end for extreme fire behavior in Eucalyptus observed in other parts of the world such as Australia [44].

Under more extreme burning conditions, many fire behavior predictions in Eucalyptus underestimate the rate of spread often by factors of 2 or more [45-47]. This raises concern that the FCCS surface fire behavior potentials may underestimate the potential fire risk for Eucalyptus planted in the southern Coastal Plain. Even though the rates of spread presented in this paper are consistent with other published studies, our environmental conditions are near the point where the discrepancies in rate of spread begin to appear.

Introducing select Eucalyptus species into the fire-prone landscape of the southern Coastal Plain raised the specter of altered fire behavior and greater risk of destructive wildfire, given the nature of wildfires in Australia where Eucalyptus are native. Although there is little empirical information on the fire behavior in Eucalyptus plantations under the weather conditions found in the southern Coastal Plain, our modeling effort focusing on fire behavior at the stand level suggests that little may differ from current conditions, given the flammable nature of the native pine species. Because we did not examine the potential for fire to spread from one stand to the next, two caveats temper this preliminary conclusion. The crown fire potential of Eucalyptus species is severalfold greater than pine, once a crown fire is initiated. This suggests that management of the shrub layer will be critical to avoid extreme fire behavior in Eucalyptus plantations. Further, we could not effectively estimate whether bark shedding of Eucalyptus would increase spotting behavior over that found in pine plantations; much depends on the nature of the environment into which firebrands are launched, the distance away, and the nature of the bark [48].

Eucalyptus species vary greatly in their bark characteristics, and species with stringy or fibrous bark present a significant spotting potential [48]. Messmate stringybark (E. oblique L'Hér.) for example is well recognized for its intense spotting up to as much as $4 \mathrm{~km}$ [49]. Gum bark eucalypts, on the other hand, are not regarded in Australia as especially hazardous, but some members of this group, the candlebarks such as E. globulus Labill., are seen in other countries to exhibit significant spotting behavior [49]. Nevertheless, the implications for managing Eucalyptus to avoid increased fire risk are for short rotation, consistent with pulpwood or bioenergy production. Site preparation with effective competition control and harvesting within 10 years should remove Eucalyptus trees before they are old enough to shed significant amounts of bark or tall shrub layer forms. Managed as a short-rotation woody crop in the southern
Coastal Plain, Eucalyptus stands will likely be harvested before bark shedding leads to a significant spotting problem. A worst case scenario would be if Eucalyptus plantations are abandoned from active management due to changing market conditions or other factors. Changes in climate, moreover, could result in more extreme fire behavior under projected hotter and drier conditions $[28,29]$.

Our modeling provides a preliminary answer to the question we posed: how fire behavior at the stand level would be affected by deployment of Eucalyptus species in the southern Coastal Plain? Future work should focus on possible effects on fire risk in the landscape. As it becomes clear which species have the greatest commercial potential for widespread planting, it will be possible to better predict their spotting potential and evaluate the applicability of available models of firebrand production and dispersal $[42,44]$ to current and future conditions in the southern Coastal Plain.

\section{Acknowledgments}

The work this paper is based upon was funded in part by a special grant from the US Forest Service Research and Development Washington Office for bioenergy research, and The authors acknowledge the support of Marilyn Buford for this work. They also express their thanks to two anonymous reviewers for providing valuable feedback that improved this paper.

\section{References}

[1] J. A. Stanturf, R. C. Kellison, F. S. Broerman, and S. B. Jones, "Productivity of southern pine plantations: where are we and how did we get here?" Journal of Forestry, vol. 101, no. 3, pp. 26-31, 2003.

[2] D. M. Wear and J. Greis, Eds., The Southern Forest Resource Assessment, General Technical Report SRS-53, USDA Forest Service, Asheville, NC, USA, 2002.

[3] R. D. Perlack and B. J. Stokes, "US billion-ton update: biomass supply for a bioenergy and bioproducts industry," Tech. Rep. ORNL/TM-2011/224, US Department of Energy, Oak Ridge National Laboratory, Oak Ridge, Tenn, USA, 2011.

[4] R. S. Zalesny, M. W. Cunningham, R. B. Hall et al., Woody Biomass from Short Rotation Energy Crops, American Chemical Society, Washington, DC, USA, 2011.

[5] M. Hinchee, W. Rottmann, L. Mullinax et al., "Short-rotation woody crops for bioenergy and biofuels applications," In Vitro Cellular and Developmental Biology_Plant, vol. 45, no. 6, pp. 619-629, 2009.

[6] D. Dougherty and J. Wright, "Silviculture and economic evaluation of eucalypt plantations in the Southern US," BioResources, vol. 7, pp. 1994-2001, 2012.

[7] R. Gonzalez, T. Treasure, J. Wright et al., "Exploring the potential of Eucalyptus for energy production in the Southern United States: financial analysis of delivered biomass-part I," Biomass and Bioenergy, vol. 35, no. 2, pp. 755-766, 2011.

[8] R. Gonzalez, T. Treasure, R. Phillips et al., "Converting Eucalyptus biomass into ethanol: financial and sensitivity analysis in a co-current dilute acid process-part II," Biomass and Bioenergy, vol. 35, no. 2, pp. 767-772, 2011.

[9] A. Pirraglia, R. Gonzalez, D. Saloni, J. Wright, and J. Denig, "Fuel properties and suitability of Eucalyptus benthamii and 
Eucalyptus macarthurii for torrefied wood and pellets," BioResources, vol. 7, pp. 217-235, 2011.

[10] C. L. Riccardi, R. D. Ottmar, D. V. Sandberg et al., "The fuelbed: a key element of the fuel characteristic classification system," Canadian Journal of Forest Research, vol. 37, no. 12, pp. 2394-2412, 2007.

[11] R. D. Ottmar, D. V. Sandberg, C. L. Riccardi, and S. J. Prichard, "An overview of the fuel characteristic classification systemquantifying, classifying, and creating fuelbeds for resource planning," Canadian Journal of Forest Research, vol. 37, no. 12, pp. 2383-2393, 2007.

[12] R. L. Myers, Living with Fire-Sustaining Ecosystems \& Livelihoods through Integrated Fire Management, Global Fire Initiative, The Nature Conservancy, Tallahassee, Fla, USA, 2006.

[13] C. Fowler and E. Konopik, "The history of fire in the Southern United States," Human Ecology Review, vol. 14, no. 2, pp. 165176, 2007.

[14] J. A. Stanturf, D. D. Wade, T. A. Waldrop, D. K. Kennard, and G. L. Achtemeier, "Fires in southern forest landscapes," in The Southern Forest Resource Assessment, D. M. Wear and J. Greis, Eds., General Technical Report SRS-53, chapter 25, pp. 607630, USDA Forest Service, Asheville, NC, USA, 2002.

[15] D. D. Wade, B. L. Brock, P. H. Brose, J. B. Grace, G. A. Hoch, and W. A. Patterson III, "Fire in eastern ecosystems," in Wildland Fire in Ecosystems: Effects of Fire on Flora, J. K. Brown and J. K. Smith, Eds., General Technical Report RMRS-42, pp. 53-96, USDA Forest Service, Ogden, Utah, USA, 2000.

[16] R. K. Myers and D. H. Van Lear, "Hurricane-fire interactions in coastal forests of the south: a review and hypothesis," Forest Ecology and Management, vol. 103, no. 2-3, pp. 265-276, 1998.

[17] T. A. Waldrop and S. L. Goodrick, Introduction to Prescribed Fires in Southern Ecosystems, Science Update SRS-054, USDA Forest Service, Asheville, NC, USA, 2012.

[18] M. Gramley, Fire in the South: A Report by the Southern Group of State Foresters, Southern Group of State Foresters, Winder, Ga, USA, 2005, http://216.226.177.78/PDFs/fire_in_ the_south.pdf.

[19] Southern Group of State Foresters, "Fire in the South 2," 2008, http://www.southernwildfirerisk.com/reports/FireInTheSouth2.pdf.

[20] R. Seager, A. Tzanova, and J. Nakamura, "Drought in the Southeastern United States: causes, variability over the last millennium, and the potential for future hydroclimate change," Journal of Climate, vol. 22, no. 19, pp. 5021-5045, 2009.

[21] D. N. Wear, Forecasts of county-level land uses under three future scenarios: a technical document supporting the Forest Service 2010 RPA assessment, General Technical Report SRS141, USDA Forest Service, Asheville, NC, USA, 2011.

[22] D. M. Theobald and W. H. Romme, "Expansion of the US wildland-urban interface," Landscape and Urban Planning, vol. 83, no. 4, pp. 340-354, 2007.

[23] D. M. Wear and J. Greis, Eds., Southern Forest Futures Project Technical Report, General Technical Report SRS-XX, USDA Forest Service, Asheville, NC, USA, In Press.

[24] J. P. Prestemon and D. T. Butry, "Time to burn: modeling wildland arson as an autoregressive crime function," American Journal of Agricultural Economics, vol. 87, no. 3, pp. 756-770, 2005.

[25] J. P. Prestemon, J. M. Pye, D. T. Butry, T. P. Holmes, and D. E. Mercer, "Understanding broadscale wildfire risks in a humandominated landscape," Forest Science, vol. 48, no. 4, pp. 685693, 2002.

[26] C. J. Gaither, N. C. Poudyal, S. Goodrick, J. M. Bowker, S. Malone, and J. Gan, "Wildland fire risk and social vulnerability in the Southeastern United States: an exploratory spatial data analysis approach," Forest Policy and Economics, vol. 13, no. 1, pp. 24-36, 2011.

[27] J. A. Stanturf and S. L. Goodrick, "Fire," in Southern Forest Futures Project Technical Report, D. M. Wear and J. Greis, Eds., General Technical Report SRS-XX, chapter 17, USDA Forest Service, Asheville, NC, USA, In Press.

[28] Y. Liu, J. Stanturf, and S. Goodrick, "Trends in global wildfire potential in a changing climate," Forest Ecology and Management, vol. 259, no. 4, pp. 685-697, 2010.

[29] Y. Q. Liu, S. L. Goodrick, and J. A. Stanturf, "Future U.S. wildfire potentialtrends projected using a dynamically downscaled climate change scenario," Forest Ecology and Management. In Press.

[30] P. de Mar and D. Adshead, "Blue gum plantation fuel and fire behavior guide," 2011, http://www.ghd.com/PDF/BlueGumFuelandFireGuide.pdf.

[31] J. S. Gould, W. L. McCaw, N. P. Cheney, P. E. Ellis, and S. Matthews, Field Guide- Fuel Assessment and Fire Behaviour Prediction in Dry Eucalypt Forest, Ensis-CSIRO, Canberra, Australia; Department of Environment and Conservation, Perth, Australia, 2007.

[32] D. V. Sandberg, C. L. Riccardi, and M. D. Schaaf, "Fire potential rating for wildland fuelbeds using the fuel characteristic classification system," Canadian Journal of Forest Research, vol. 37, no. 12, pp. 2456-2463, 2007.

[33] R. C. Rothermel, A Mathematical Model for Predicting Fire Spread in Wildland Fuels, General Technical Report INT-115, USDA Forest Service, 1972.

[34] D. V. Sandberg, C. L. Riccardi, and M. D. Schaaf, "Reformulation of Rothermel's wildland fire behaviour model for heterogeneous fuelbeds," Canadian Journal of Forest Research, vol. 37, no. 12, pp. 2438-2455, 2007.

[35] M. D. Schaaf, D. V. Sandberg, and C. L. Riccardi, "A conceptual model of crown fire potential based on the reformulated Rothermel wildland fire behavior model," Canadian Journal of Forest Research, vol. 37, pp. 2464-2478, 2007.

[36] C. E. Van Wagner, "Conditions for the start and spread of crown fire," Canadian Journal of Forest Research, vol. 7, pp. 2334, 1977.

[37] M. E. Alexander, Crown fire thresholds in exotic pine plantations of Australasia [Ph.D. thesis], Australian National University, Canberra, Australia, 1998.

[38] J. H. Scott and R. D. Reinhardt, "Assessing crown fire potential by linking models of surface and crown fire behavior," Research Paper RP-RMRS-029, USDA Forest Service, 2001.

[39] S. J. Prichard, R. D. Ottmar, D. V. Sandberg, P. C. Eagle, A. G. Andreu, and K. Swedin, "FCCS User's Guide, version 2.2," 2011, http://www.fs.fed.us/pnw/fera/fccs/fccs_2_2_user_ guide.pdf.

[40] P. L. Andrews, C. D. Bevins, and R. C. Seli, "BehavePlus fire modeling system, version 4.0: user's guide,” General Technical Report RMRS-GTR-106, Department of Agriculture, Forest Service, Rocky Mountain Research Station, Ogden, Utah, USA, 2005.

[41] M. E. D. Poore and C. Fries, "The ecological effects of Eucalyptus," Forestry Paper 59, FAO, Rome, Italy, 1985.

[42] J. S. Gould, W. L. McCaw, N. P. Cheney, P. E. Ellis, I. K. Knight, and A. L. Sullivan, Project Vesta. Fire in Dry Eucalypt Forest: Fuel Structure, Fuel Dynamics, and Fire Behaviour, EnsisCSIRO, Canberra, Australia; Department of Environment and Conservation, Perth, Australia, 2007.

[43] D. Buckley, J. K. Berry, T. Spencer, and D. Carlton, "Quantifying wildland fire risk in the South," 2006, http://www 
.southernwildfirerisk.com/downloads_reports/Sanborn\%20\%20Quantifying_Wildland_Fire_Risk_in_South.pdf.

[44] N. P. Cheney, J. S. Gould, W. L. McCaw, and W. R. Anderson, "Predicting fire behaviour in dry eucalypt forest in southern Australia," Forest Ecology and Management, vol. 280, pp. 120 $131,2012$.

[45] N. D. Burrows, Experimental development of a fire management model for Jarrah (Eucalyptus marginata) forest [Ph.D. thesis], Department of Forestry, Australian National University, Canberra, Australia, 1994.

[46] N. D. Burrows, "Fire behaviour in jarrah forest fuels: 2. Field experiments," CALMScience, vol. 3, no. 1, pp. 57-84, 1999.

[47] R. Rawson, P. Billing, and S. Duncan, "The 1982-83 forest fires in Victoria," Australian Forestry, vol. 46, pp. 163-172, 1983.

[48] F. Hines, K. G. Tolhurst, A. A. G. Wilson, and G. J. McCarthy, Overall Fuel Hazard Assessment Guide, Fire and Adaptive Management Report, no. 82, State of Victoria Government Department of Sustainability and Environment, Melbourne, Australia, 4th edition, 2010.

[49] P. F. M. Ellis, "Fuelbed ignition potential and bark morphology explain the notoriety of the eucalypt messmate 'stringbark' for intense spotting," International Journal of Wildland Fire, vol. 20, pp. 897-907, 2011. 

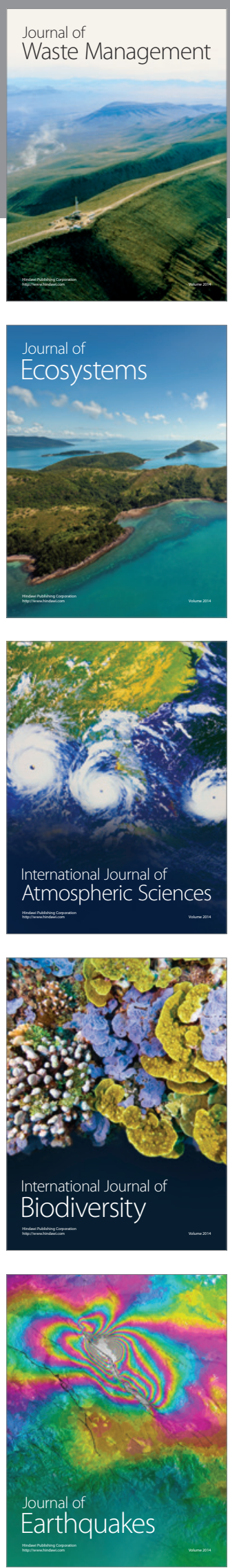
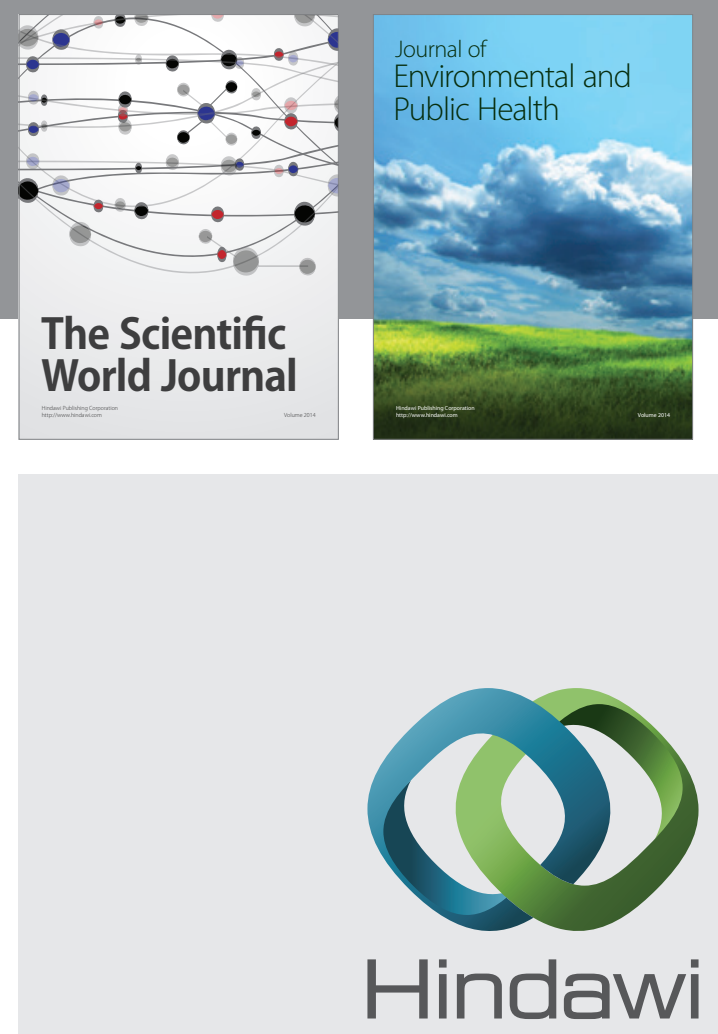

Submit your manuscripts at

http://www.hindawi.com
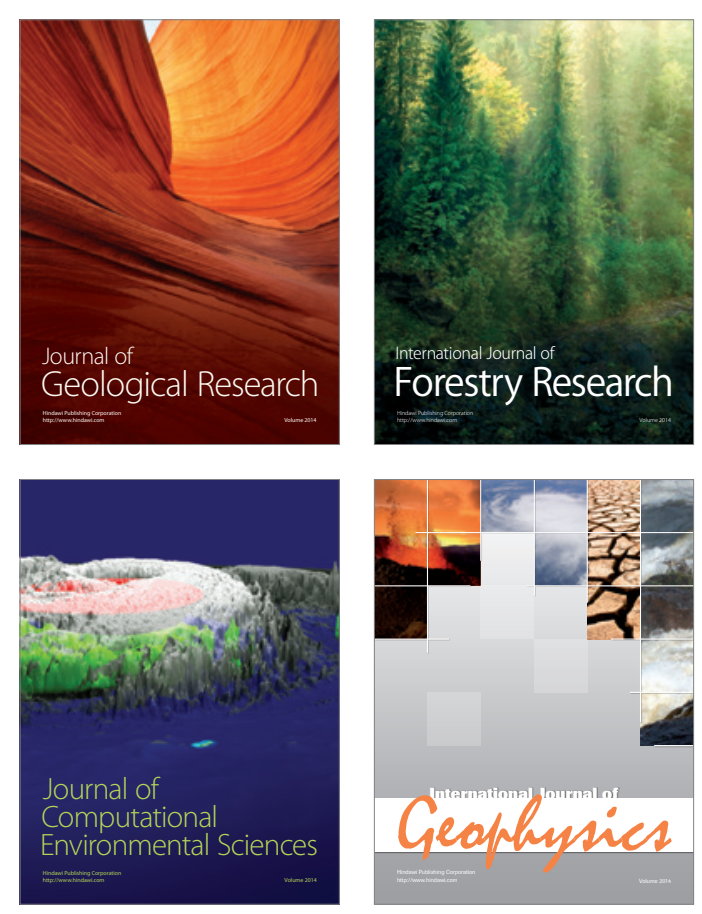
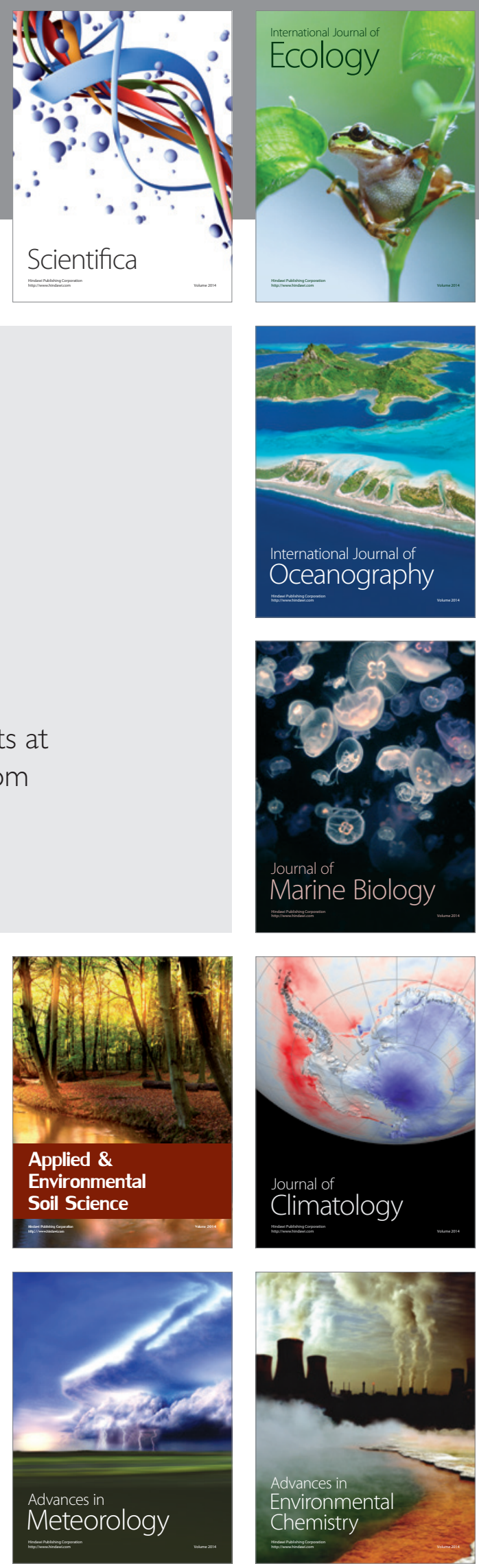